\title{
ANALYSIS OF THE ATTITUDE PATIENTS FROM RURAL AND PATIENTS FROM URBAN AREAS IN BOSNIA AND HERZEGOVINA HAVE TOWARDS SKIN TUMORS
}

\section{ANALIZA ODNOSA PACIJENATA SEOSKE I URBANE SREDINE U BOSNI I HERCEGOVINI PREMA TUMORIMA KOŽE}

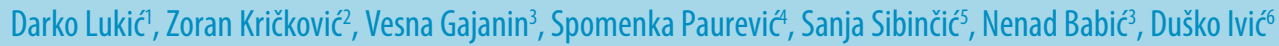

\section{Summary}

A prospective study, which lasted from September 2014 to October 2016, covered the subjects who were examined for various benign tumor changes on the skin. The examinees were divided into 2 groups. The first group A (92 examinees) was composed of the examinees who inhabited a rural area. The second group B (98 examinees) was consisted of examinees who lived in an urban environment. The analyzed examinees gravitate towards rural and urban areas of Banja Luka, Gradiska, Stanari, Prijedor and Teslic in Bosnia and Herzegovina.

The aim of this study is to analyze the attitude of examinees from rural and urban areas towards skin tumors. Parameters that were used for comparison of results are: personal attitude to skin tumors and previous skin examinations.

There was no statistically significant difference in terms of prejudices among the respondents: that there is no risk of skin cancer, if a person is not exposed to the sun, and/or if changes in the skin are innate, as well as in the number of examinees who said they were not afraid of a skin tumor. In group $A$ the number of examinees that have no opinion about skin tumors is three times higher, while in group B the number of examinees who said that they had a phobia of skin cancer is three times higher.

It turned out that regular self-examination of the skin in group A is performed only by 7 (7.6\%) examinees, while in group B it is done by 21 (21.5\%) examinees, which proved to be statistically significantly different. Occasionally skin examination by a specialist family doctor (and/or a dermatologist) has been performed by $3(3.3 \%)$ examinees of group A and 10 (10.3\%) from group B. 4 (4.1\%) examinees from group B and no one from group A perform dermoscopic examination occasionally.

It was found that regular dermoscopy inspections or skin examinations by a specialist family doctor and/or dermatologist have not been done by any examinees from both analyzed groups.

Attitude toward skin tumors of group A is more leisurely (less responsible), so for that group there is a possibility of higher risk degree for late diagnosis of malignant skin tumors.

Keywords: skin, tumors

\section{Sažetak}

Prospektivnom studijom, koja je trajala od septembra 2014. do oktobra 2016. godine, obuhvaćeni su ispitanici koji su pregledani radi različitih benignih tumorskih promjena na koži. Ispitanici su podijeljeni u 2 grupe. Prvu, grupu A (92 ispitanika), činili su ispitanici koji su nastanjeni u seoskoj sredini. Drugu, grupu B (98 ispitanika), činili su ispitanici koji su nastanjeni u gradskoj sredini. Analizirani ispitanici gravitiraju seoskim i urbanim sredinama Banja Luke, Gradiške, Stanara, Prijedora i Teslića u Bosni i Hercegovini.

Cilj rada je analiza odnosa pacijenata seoske i urbane sredine prema tumorima kože. Parametri za poređenje rezultata bili su: lični stav ispitanika prema tumorima kože i prethodni pregledi kože.

Nije pronađena statistički bitna razlika u pogledu predrasude kod ispitanika: da nema opasnosti od tumora kože, ukoliko se osoba ne izlaže suncu, i/ili ukoliko su promjene na koži prirođene, kao i u broju ispitanika koji su izjavili da se ne plaše tumora kože. U grupi A je trostruko više ispitanika koji nemaju nikakav stav o tumorima kože, dok je u grupi B tri puta više ispitanika koji su izjavili da imaju fobiju od kancera kože.

Ispostavilo se da redovan samopregled kože u grupi A izvodi svega 7 (7,6\%) ispitanika, a u grupi B 21 (21,5\%), što se pokazalo statistički značajno različito. Povremene preglede kože kod specijaliste porodične medicine (i/ili dermatologa) praktikuju 3(3,3\%) ispitanika iz grupe A i 10(10,3\%) iz grupe B. Pouremeni dermoskopski pregled praktikuju $4(4,1 \%)$ ispitanika iz grupe B, a iz grupe A ni jedan.

Uočeno je da redovne dermoskopske preglede ili preglede kože kod specijaliste porodične medicine i/ili dermatologa, ne izvodi ni jedan ispitanik u obe analizirane grupe.

Odnos prema tumorima kože ispitanika grupe A je više ležeran (manje odgovoran), pa je za tu grupu moguć viši stepen rizika od kasne dijagnoze malignih tumora kože.

Ključne reči: koža, tumori 


\section{INTRODUCTION}

According to their biological behavior skin tumors can be benign, precancerous and malignant. According to histogenetic origin they can be divided into keratinocyte, melanocyte, adnexal and mesenchymal (vascular, hematolymphoid, origin of muscle and connective tissue) (1).

Not all skin changes are tumors, especially not malignant ones, but it does not mean that all changes within the clinical picture should not be analyzed very subtly and seriously. The strategy of a good treatment of skin cancer has to take all possible changes in the skin into account, which is (or not) the tumor, and their repercussions on the treatment of skin diseases $(2,3)$.

Benign skin changes are more common than malignant, but they often worry patients and there should be serious professional considerations.

The importance of early diagnosis of skin cancer is invaluable. Since it is easy and simple to examine the skin by inspection, palpation, magnifying glass, dermoscopy etc. it is logical to assume that an early diagnosis will become dominant over time. However, despite the progress in knowledge about skin cancer the diagnosis is often delayed.

Improvements of diagnostic methods and additional efforts in the clinical, dermoscopic and $\mathrm{PH}$ verification of small, initial skin lesions contribute to the implementation of non-radical, limited surgical interventions. Today, most authors use optimally radical tumorectomy of non-melanocytic skin cancer (NMSC) of small diameter, when additional therapy is not necessary (4-8).

It is still an imperative to use more massive education of the population to suppress prejudices about skin tumors and favor professional and scientific truth.

\section{ThE AIM OF THE STUDY}

The aim of this study is to analyze the attitude of examinees from rural and urban areas towards tumor changes on the skin.

\section{MATERIALS AND METHODS}

A prospective study, which lasted from September 2014 to October 2016, covered the examinees that were examined for various benign tumor changes on the skin. The examinees were divided into 2 groups. The first group A (92 examinees) was composed of the examinees who inhabited a rural area. The second group B (98 examinees) contained the examinees who lived in the city.
Analyzed examinees gravitate towards rural and urban areas of Banja Luka, Gradiska, Stanari, Prijedor and Teslic.

The analyzed patients came to be examined by a family doctor, a dermatologist and/or plastic surgeon, or they were indirectly interviewed and referred by urologists and / or gynecologist.

The observed parameters are examinees' gender and relevant findings of cutaneous changes as a reason for coming to skin examination (Tables 1 and 2). Parameters for results comparison were personal attitude to skin tumors and previous skin examination (Tables 3 and 4 ).

Table 1. Gender

$\begin{array}{lll}\text { gender } & \text { Group A } & \text { Group B } \\ \text { Female } & 59(64,1 \%) & 57(58,1 \%) \\ \text { Male } & 33(35.9 \%) & 41(41.9 \%) \\ \text { Total } & 92(100 \%) & 98(100 \%)\end{array}$

\begin{tabular}{lll}
\multicolumn{3}{c}{ Table 2. Clinical finding } \\
Clinical finding & Group A & Group B \\
\hline Seborrheic keratosis & $16(17,3 \%)$ & $19(19,4 \%)$ \\
\hline Dermatofibroma & $3(3,3 \%)$ & $4(4,1 \%)$ \\
Hemangioma & $15(16,3 \%)$ & $10(10,2 \%)$ \\
Papilloma (fibroepithelial polyp) & $8(8,7 \%)$ & $11(11,2 \%)$ \\
Nevi & $50(54,4 \%)$ & $54(55,1 \%)$ \\
Total & $92(100 \%)$ & $98(100 \%)$
\end{tabular}

\section{RESUlts}

The research results are shown in Table 4 and Table 5 . The parameters for result comparison were attitude to skin tumors and previous skin examination.

Table 3. Examinee's attitude to skin tumors

\begin{tabular}{|c|c|c|}
\hline Attitude to skin tumors & Group A & Group B \\
\hline There is no particular attitude to skin tumors & $15(16,3 \%)$ & $5(5,1 \%)$ \\
\hline There is a phobia of skin cancer & $9(9,8 \%)$ & $28(28,5 \%)$ \\
\hline Is not afraid of skin cancer & $17(18,4 \%)$ & $11(11.3 \%)$ \\
\hline $\begin{array}{l}\text { Does not expose the skin to the sun and } \\
\text { there is no reason for concern }\end{array}$ & $13(14,2 \%)$ & $24(24,5 \%)$ \\
\hline $\begin{array}{l}\text { Changes are congenital and there is no re- } \\
\text { ason for concern }\end{array}$ & $24(26,1 \%)$ & $26(26,5 \%)$ \\
\hline Does not want to explore the skin & $14(15,2 \%)$ & $4(4,1 \%)$ \\
\hline Total & $92(100 \%)$ & $98(100 \%)$ \\
\hline
\end{tabular}

Table 4. Previous skin examinations

$\begin{array}{lll}\text { Previous skin examination } & \text { Group A } & \text { Group B } \\ \text { Self-Examination } & & \\ \text { No } & 70(76,1 \%) & 51(52,0 \%) \\ \text { Occasionally } & 15(16,3 \%) & 26(26,5 \%) \\ \text { Regularly } & 7(7,6 \%) & 21(21,5 \%) \\ \text { Examination by a family doctor and/or dermatologist } \\ \text { No } & 89(96,7 \%) & 88(89,7 \%) \\ \text { Occasionally / if necessary } & 3(3,3 \%) & 10(10,3 \%) \\ \text { Regularly } & 0(0 \%) & 0(0 \%) \\ \text { Dermoscopy } & & \\ \text { No } & 92(100 \%) & 94(95,9 \%) \\ \text { Occasionally / if necessary } & 0(0 \%) & 4(4,1 \%) \\ \text { Regularly } & 0(0 \%) & 0(0 \%) \\ \text { Total } & 92(100 \%) & 98(100 \%)\end{array}$


Statistical analysis of the observed groups A and B is as follows: Statistical comparison analysis (Chi -Square Tests) of the parameters results of the examinee's personal opinion about skin tumors, showing that Chisquare $=24.764 \mathrm{df}=5$ significance $\mathrm{p}=00: 00<0.05$, which is statistically significantly different.

At the same time, a statistically significant difference was observed in terms of the characteristics of "self-examination of the skin" where the Chi-square $=12.758 \mathrm{df}$ $=2$ significance $\mathrm{p}=0.002<0.01$.

\section{Discussion}

The analysis included 190 examinees with benign skin tumors. Their attitude towards these tumors was analyzed. Examinees were divided according to their place of living to those who live in villages and those who live in urban areas.

Benign tumor lesions are numerous and any of them can cause concern. The reason of layman' concerns are the most often nevi and seborrheic keratosis.

Nevi are hamartomas, ie, benign formations that occur because of congenital developmental abnormalities with the appearance of malformations composed by ripe or nearly ripe structure (1). Nevi vary considerably in their clinical appearance: straight changes, mildly elevated changes (often with raised center and flat periphery), papillomatous changes, dome and stalk changes (2).

Seborrheic keratoses are benign papillomatous changes, originating from the epidermis. They are placed on the seborrheic areas of the face, chest and back. They are clearly limited, infiltrating the bases. They can be flat or slightly raised with light to dark brown velvet surface or they can be rough with keratoid caps. 1 Acanthotic keratosis is a common type of seborrheic keratoses where occasionally so-called bovenoid transformation, i.e. the creation of basal cell carcinoma (BCC) or squamous cell (PCC) carcinoma "in situ", inside of seborrheic keratosis $(1,2)$.

Our research has shown mainly equal distribution of benign skin changes in both groups. Nevi dominated in group A with $54.4 \%$ and in group B with $55.1 \%$ examinees. The other two skin changes are usually seborrheic keratoses (17.3\% examinees from group A, and 19.4\% from group $\mathrm{B}$ ), and hemangiomas $16.3 \%$ examinees in the group A and $10.2 \%$ in the group $B$.

At the same time, our research has shown that the total of $20(10.5 \%)$ examinees have no personal attitude to skin tumors. This approach to skin tumors is predominant in rural areas with 15 (16.3\%) of examinees versus 5 (5.1\%) of the respondents who live in the city.
Overall, in both groups there were 37 (19.4\%) who had a phobia of malignant skin tumors. In the urban population there are hree times more examinees 28 (28.5\%), stating that they have a phobia of skin cancer, compared to only 9 $(9.8 \%)$ like-minded people who live in the village.

Overall, in both groups there were 28 (14.7\%) examinees who said they were not afraid of skin cancer. By this characteristic, there are no statistically significant differences between the two groups.

Belief that there is no risk of skin cancer if the one is not exposed to the sun light, and/or that skin changes are not dangerous if they exist from birth, was found in 87 (45.7\%) examinees in both groups. In Group A this prejudice is characteristic for 37 (19.4\%) examinees, while in group B 50 (26.3\%) examinees. In terms of these prejudices there is no significant difference in the attitude of the examinees.

The total number of examinees in both groups, which are benevolent towards skin changes and "do not want to examine their skin", is 18 (9.5\%). This attitude is dominant among the examinees from rural area 14 (15.2\%) versus 4 (4.1\%) the examinees who live in the city. Thus, according to this characteristic it is found to be a significant difference.

The possibility of early diagnosis of suspicious skin lesions implies responsible and regular self-examination of the skin, and consulting a doctor of family medicine and if there is still any doubt, dermatologist and plastic surgeon are to be consulted as well (2-5).

Clinical diagnosis of pigmented and non-pigmented skin lesions is often not accurate (3-8). In cases where a suspicious, atypical tumor of the skin exists, it is wise to examine the suspicious lesion by computer dermoscopy. The sensibility of the digital computer dermoscopy (when it is performed by an experienced specialist) is from $84 \%$ to $96 \%$, and specificity is from $98 \%$ to $100 \%$ $(9,10)$.

Dermoscopy is now widely used in the EU, USA and Australia. It is non-invasive, painless and bloodless, superficial contact microscopy, with "in vivo" structure visualization of the epidermis and dermis i.e., detection of changes that are not visible by the inspection examination or magnifying glass. This diagnosis does not imply any adverse effects, can be repeated indefinitely, regardless the age of patient (11-17).

Our testing has shown that 121 (63.6\%) of examinees of both groups, generally do not perform self-examination of the skin. A regular skin self-examination in the rural population is carried out by $15(16.3 \%)$ examinees and in the city's population by $26(26.5 \%)$. 
At the same time, the research has shown that regular self-examination of the skin in the rural population is performed only by 7 (7.6\%) examinees, while in urban population it is done by $21(21.4 \%)$, which proved to be statistically significantly different.

In the previous period, there were $3(3.3 \%)$ of examinees from rural areas and $10(10.3 \%)$ from the city that were examined by a doctor of family medicine and/or a dermatologist, because of skin changes, which was significantly different. Considering both groups 177 (93.1\%) examinees had no earlier skin examinations on any issue.

4 (4.1\%) examinees of the urban population had had a dermoscopic examination before, while examinees from rural area had not.

The observed groups are identical in terms of regular dermoscopic skin examination, or skin exam performed by a doctor of family medicine and/or dermatologist, since such no analyzed examinee had done that. Also, among the examined groups there is no statistically significant difference in terms of the number of those who do not have any kind of skin inspections of any scope or method.

By the way, the majority of both groups have never heard of computer dermoscopy. A small number of examinees learned about the procedure from media.

\section{ConCLusion}

There was no statistically significant difference in terms of prejudices among the respondents: that there is no risk of skin cancer, if a person is not exposed to the sun, and / or if changes in the skin are innate, as well as in the number of examinees who said they were not afraid of skin cancer. In group A the number of examinees that have no opinion about skin tumors is three times higher, while in group $B$ the number of examinees who said that they had a phobia of skin cancer is three times higher.

It turned out that regular self-examination of the skin in group A was performed only by 7 (7.6\%) examinees, while in group B it was performed by $21(21.5 \%)$ examinees, which is proved to be statistically significantly different. Occasionally skin examination by a specialist of family medicine (and/or a dermatologist) has been performed by 3 (3.3\%) examinees from group $\mathrm{A}$ and 10 (10.3\%) from group B. 4 (4.1\%) examinees from group B and no one from group A occasionally perform dermoscopic examination.

It was found that regular dermoscopic inspections or skin examinations by a specialist of family medicine and/or dermatologist have not been performed by any examinees from both analyzed groups.

Attitude toward skin tumors of the group A is more leisurely (less responsible), so for that group there is a possibility of higher risk degree for late diagnosis of malignant skin tumors.

\section{References}

1. Zrnić B. Dermatovenerologija. Medicinski fakultet Banja Luka, 2012; 224-227

2. Lukić D.: Tumori kože, Medicinski fakultet Banja Luka, 2009; 45-52

3. Tannous ZS, Milhm MC Jr, Sober AJ, Duncan L. Congenital melanocytic nevi: Clinical and histopathological features, risk of melanoma, and clinical management. J Am Acad Dermatol 2007; 52:197-203

4. Padgett JK, Hendrix JD Jr. Cutaneous malignancies and their management. Otolaryngol Clin North Am 2001; 34:523-553

5. Lear JT, Smith AG. Basal cell carcinoma. Postgrad Med J 1997; 73:538542

6. Rogers, HW, Weinstock, MA, Harris, AR, et al. Incidence estimate of nonmelanoma skin cancer in the United States, 2006. Arch Dermatol 2010; 146(3):283-287

7. Anwar, U., Ghazal, A.S.K., Ahmad, M., Sharpe, D.T. Horrifying basal cell carcinoma forearm lesion leading to shoulder disarticulation. Plast Reconstr Surg, 2006; 117-9

8. McCutcheon, B, White, K, Kotwall, C, Germolic, D, Rebolloso, Y, Hamann, M.S, Stiles, A. A preliminary study of imiquimod treatment in variants of basal cell carcinoma. Am Surg, 2005; 71(8): 662-5

9. Kittler $\mathrm{H}$, Pehamberger $\mathrm{H}$, Wolff $\mathrm{K}$ et al. Diagnostic accuracy of dermoscopy. Lancet Oncol. 2002; 3: 159-65

10. Kittler H, Binder M. Follow-up of melanocytic skin lesions with digital dermoscopy: risks and benefits. Arch.Dermatol. 2002; 138: 1379

11. Bauer J, Blum A, Strohhacker U et al. Surveillance of patients at high risk for cutaneous malignant melanoma using digital dermoscopy. Br.J. Dermatol. 2005; 152: 87-92
12. Takenouchi T, Takahashi A, Tsuchiya K. Diagnostic accuracy of facial pigmented basal cell carcinoma by dermoscopy. Skin Cancer (Japan) 2008; 23: $166-170$

13. Peris K, Altobelli E, Ferrari A et al. Interobserver agreement on dermoscopic features of pigmented basal cell carcinoma. Dermatol Surg, 2002; 28: 643-645

14. Weedon D, Marks R, Kao GF, Harwood CA. Seborrheic keratosis. In: Leboit PE, Weedon D, Sarasin A, eds. Pathology and Genetics of Skin Tumours. Lyon: IARC Press, 2006; 41-43.

15. Braun RP, Rabinovitz HS, Krischer J et al. Dermoscopy of pigmented seborrheic keratosis: a morphological study. Arch Dermatol 2002; 138: $1556-1560$

16. Kopf AW, Rabinovitz H, Marghoob A et al. "Fat fingers": A clue in the dermoscopic diagnosis of seborrheic keratoses. J Am Acad Dermatol 2006; 55: 1089-1091

17. Braun RP, Rabinovitz H, Oliviero M, Kopf AW, Saurat JH: Dermoscopic diagnosis of seborrheic keratosis. Clin Dermatol 2002; 20: 270-272 